\title{
An Environmental Impact Assessment of Cement Pollution in Ariyalur District of Tamil Nadu, India
}

\author{
K. Kayalvizhi*, J. S. Amarnath and B. Sivasankari \\ Department of Agricultural Economics, Tamil Nadu Agriculture University, Coimbatore \\ Agricultural College and Research Institute, Madurai 625104 TN, India, India \\ *Corresponding author
}

\section{A B S T R A C T}

\section{Keywords}

Externalities, Damage function, Hedonic model, Averting expenditure, Contingent valuation, Land quality, Water quality, Willingness To Pay, Willingness To accept compensation and health production function

\section{Article Info}

Accepted:

17 September 2020 Available Online: 10 October 2020
The present study concentrates on the externalities of air pollution due to cement industries and quantification of these externalities with environmental valuation techniques and household health production function. The study revealed that the decline in crop production was directly related with pollution intensity. The agriculture damage function related the value of agriculture damages to averting expenditure of land and irrigation water and quality indices of land and water quality. The hedonic model revealed that the farm income and distance between farm and polluted industries have been found significant in deciding the value of cultivated lands. The pollution averting expenditure incurred by the farmer's increased with increase in the intensity of pollution. Contingent valuation study revealed that the proportion of farmers WTP (Willingness To Pay) was high for severely affected farms and proportion of Willing To Accept the Compensation was high for low affected farmers. Maximum WTP for seriously affected, moderately affected and low affected farmers were Rs.2850 per year, Rs.1950 per year, Rs.900 per year respectively. Health production function study revealed that most of the farmer was suffering from chronic illness and it was the main reason for work days lost. The solution to cement pollution problem should take cognizance of intensity of externalities and accordingly appropriate reclamation schemes may be framed. The Government can also take note of the WTP of farmers and accordingly, collect the amount from polluters and pay to farmers.

\section{Introduction}

Cementing industries are the most important polluting industries in India. In Ariyalur district of Tamil Naduseven cement factories are located. Among the seven factories, three factories are located in Ariyalur block.
Cement pollution led to various negative externalities on land, water, crop and human health. In this article, the negative externalities on land, water and crops especially in the form of yield decline, decline in water quality and land quality, averting or defensive expenditure for land and water and 
health status of farmers were studied separately. Further, environmental valuation techniques and household health production function were also attempted in the study to gain a finer perspective of cement pollution.

\section{Materials and Methods}

\section{Sampling design}

Ariyalur district was selected purposively for the study since it faces air pollution problem due to location of cement industrial plants. Among the six blocks of district, Ariyalur block was affected by cement industrial pollution due to location of cement plant and emission of dust particles and hence this block was selected purposively. In this block, the villages were classified into four categories namely severely affected, moderately affected, low affected and nonaffected based on the location of villages from cement industries.

The farms within 10 Kilometres of cement industry were considered as seriously affected and the villages selected were Kallankuriche, Thamaraikulam, Manakudi and Koviliankudikadu. Farms within 20 Kilometres from the cement industry were considered as moderately affected and the selected villages were Palayakudi, Govindapuram, Mannuzhi and Kadugoor. Low affected farms were which are located 30 Kilometres from the cement industry and the villages selected were Reddipalayam, Ayanathur, Anandavadi and Thelur. Non affected farms were which were not faced by pollution and the selected villages were Kumuliyam, Thathanur, Suthamali and Palur. Finally, from each selected village, 10 farmers were selected at random and the sample size constituted 160 farmers. Thus multi-stage random sampling was adopted for the study.

\section{Production change technique}

The production change method involved output ' $q$ ' measurable cases which is sold in market with price ' $p$ '. The economic value of change in resource supply is the value of the production change in crop that would accompany it at constant input of other factors. In present study, the change in crop production and animal husbandry production were analyzed between seriously affected, moderately affected, low affected and non affected farms.

\section{Damage function}

The damage function employed in the study was

Yield $=f\left(X_{1}, X_{2}, X_{3}, X_{4}\right)+\mu$

Where,

YIELD $=$ Yield damage in rupees per hectare $\mathrm{X}_{1}=$ Expenditure on averting input for land in rupees per hectare

$\mathrm{X}_{2}=$ Expenditure on averting input for irrigated water per hectare

$\mathrm{X}_{3}=$ An index for quality on land (poor-1, average-2, good-3)

$\mathrm{X}_{4}=$ An index for quality on water (poor -1 , average-2, good-3)

$\mu_{1}=$ random error

\section{Averting expenditure}

The averting expenditure approach realizes the fact purchased input could be used to mitigation the effects of pollution. Thus, the averting expenditure included the expenditure on mitigating efforts before pollution occurrence and investment on purchased input for reduction of deleterious effects after pollution occurrence (Cropper and Oates, 1992). This averting expenditure was identified for the study based on the above author views and also relevant to the damage incidences of water pollution on crop land, drinking water, human and animal health. 


\section{Hedonic pricing technique}

The hedonic pricing technique is used to estimate the value of environmental amenities that affect prices of marketed good (Amarnath and Krishnamoorthi, 2001). The method is based on assumption that people value the characteristics of goods or services it provides, rather than the good itself. Thus prices will reflect the value of a set of characteristics, including environmental characteristics that people consider important when purchasing the good (Liu et al., 2018).

The hedonic pricing method may be used to estimated economic benefit or cost associated with environmental quality, included air pollution, water pollution, noise pollution and soil pollution (Komarova, 2009). Hedonic model is used to find out the value of agricultural land in relation to prices of attributes (Maddsion, 2000). It can be done through hedonic price function which describes the equilibrium relationship between land values and attributes.

Hedonic model formulated for present study was of the following

$\mathrm{VCL}=\alpha_{\mathrm{o}}+\alpha_{1} \mathrm{X}_{1}+\alpha_{2} \mathrm{X}_{2}+\alpha_{3} \mathrm{X}_{3}+\alpha_{4} \mathrm{X}_{4}+\alpha_{5} \mathrm{X}_{5}+\mu_{1}$

Where

VLC $=\quad$ Value of crop land

$\mathrm{X}_{1}=$ Farm income (in Rs/year)

$\mathrm{X}_{2}=$ Land quality index (poor-1,

average-2, good-3)

$\mathrm{X}_{3}=$ water quality index (poor-1, average-2, good -3 )

$\mathrm{X}_{4}=$ Distance between the farm and cement plant (in kilometer)

$\mathrm{X}_{5}=$ Area under fallow

$\alpha_{0}=$ regression constant

$\alpha_{1}$ to $_{5}=\quad$ regression coefficients

$\mu_{1}=$ error term

\section{Contingent valuation technique}

Contingent valuation method is most wellknown, seeking personal valuations for increases or decreases in quality of some good or services, contingent upon a hypothetical market. It is a method of establishing a monetary value for a good or services by asking people what they are prepared to pay for it. This method seeking to determine a level of payment acceptable to most of people or to accept compensation for a degraded environment (Ami et al., 2014). This involved a resource by putting a monetary value on the response of the people affected by the change in the status of the environment. Contingent valuation method is based on interviewing of WTP (willingness to pay) by the demanders, who reveal their preferences based on income and other consideration (Ligus, 2018). Contingent valuation method is applied essentially asking people what they are WTP for the benefit. The compensating variation measure gives how much the consumer is willing to pay to move to a higher utility due to higher public good provision (willingness to pay).The equivalent variation needed for the consumer to forego the increase in public good provision (willingness to accept) (Sun $e t$ al., 2016).

In present study, double-dichotomous choice contingent valuation procedure was adopted since this valuation procedure was found to be asymptotically more efficient (Michael Hanemann, 1991). This approach involved asking a respondent whether he or she is willing to pay as per chosen amount. If the answer is yes, the respondent is asked again as to whether he or she is willing to pay a pre chosen amount. If the answer is no, the respondent is asked again as to whether he or she is willing to pay a pre chosen lower amount. Especially in the present study, after eliciting double- dichotomous response from the respondents, an open ended maximum 
willingness to pay question was to get precise value.

\section{Household Health production function}

Household Health production function model was used to estimate the economic benefits from reduced morbidity due to reduction in cement industrial air pollution.

The household health production function can be written as

$\mathrm{H}=\mathrm{H}(\mathrm{M}, \mathrm{Z})$

where,

$\mathrm{H} \quad=$ Number of work days lost due to illness.

M =Mitigating activities which include medicinal cost and doctor consultation.

$\mathrm{Z} \quad=$ Vector of other health and socio economic characteristics of respondents.

The analysis carried out for severely, moderately and low affected farms. The Cobb-Douglas regression was found to be the best one for the all categories of affected farms.

$Y_{i}=f\left(X_{1}, X_{2}, X_{3}, X_{4}, X_{5}\right)+\mu_{1}$

$\mathrm{Y}_{\mathrm{i}} \quad=$ Working days lost per year

$\mathrm{X}_{1} \quad=$ Age of respondent in year

$\mathrm{X}_{2} \quad=$ Household head's education (sum of

year in school and college)

$\mathrm{X}_{3} \quad=$ Household income in rupees per year

$\mathrm{X}_{4}=$ Medical expenditure in rupees per year

$\mathrm{X}_{5} \quad=$ Health status (1-choronic illness,0otherwise)

$\mu_{1} \quad=$ Errorterm

\section{Results and Discussion}

\section{Land quality deterioration}

Land quality deterioration details in severe, moderate and low affected farms are presented in table 1 . The land quality index was fixed in a three point scale of one for poor land quality, two for average land quality and three for good land quality. The poor land quality was highest in severely affected farms with a proportion of 72.50 per cent. Average and good land quality was high in low affected farms with a proportion of 62.50 per cent and 22.50 per cent. Thus, the land quality was directly related to pollution intensity in the study area.

\section{Fallow lands and yield decline}

The details of cultivable lands turning to fallow lands and yield decline of crops and land value are presented in table 2 . It could be observed from the table that fallow land was higher in seriously affected farms with 1.51 hectares followed by moderately affected farms with 1.25 hectares and low affected farms with 0.23 hectares. The year of fallow had marginal difference between severely affected and moderately affected farms with 18.59 hectares and 18.44 hectares. Thus it could be inferred that cement pollution led to fallow lands and the increase in pollution intensity resulted in increased fellow land.

In maize crop, the highest yield decline was observed in severely affected farms with 20.52 quintal per hectare followed by moderately affected and low affected farms with 7.32 quintal per hectare and 5.35 quintal per hectare respectively. In cotton, the highest yield decline was observed in severely affected farms with 10.14 quintal per hectare followed by moderately affected and low affected farms with 9.25 quintal per hectare and 7.35 quintal per hectare. In sugarcane and groundnut yield decline was high in severely affected farm with 5.35 quintal per hectare and 11.19 quintal per hectare. Cement pollution was the major factor which influenced these externalities with 92.50 per cent and 75.00 per cent in severely affected 
and moderately affected farms. Drought was the major factor for yield decline in low affected farms with 50.00 per cent which was followed by cement pollution and pest and disease incidence with 37.50 per cent and 12.50 per cent respectively.

The land value was lowest in severely affected farms with Rs. 16.90 lakh per hectare followed by moderately affected farms with 28.63 lakh per hectare and lastly with low affected farms with Rs. 32.68 lakh per hectare which was coincided with pollution intensity.

\section{Averting expenditure or defensive expenditure for land}

The details of land based averting or defensive expenditure of sample farms are presented in table 3. It could be observed from the table that averting expenditure of land was high in severely affected farms with 14339.78 rupees per hectare followed by moderately affected farms with expenditure of 10559.42 rupees per hectare and low affected farms with expenditure of 6450.56 rupees per hectare. For organic manure, the affected farms had highest expenditure and it was 59.69 percent, 62.98 per cent and 72.09 per cent for severe, moderate and low affected farms. The next highest expenditure was additional seed for crops and ammonium sulphate application. The proportion of expenditure for additional seed for crops to total expenditure was 16.42 per cent, 21.38 per cent and 13.60 per cent and the proportion of expenditure on Ammonium Sulphate to total expenditure was 15.44 per cent, 9.65 per cent and 12.28 percent for severe, moderate and low affected farms respectively. Gypsum application was lowest in all affected farms. The averting expenditure was high in affected farms and the increase was 122.30 per cent and 63.70 per cent in severely and moderately affected farms over the low affected farms.

\section{Water quality deterioration}

The details of water quality and averting expenditure on water in the three categories of affected farms are presented in table 4 . Water quality index was developed in three point scale of one for poor quality, two for average quality and three for good quality. Poor water quality was high in severely affected farms with a proportion of 85.57 per cent, average water quality was high in moderately affected farms with a proportion of 51.43 per cent and good water quality was high in low affected farms with a proportion of 36.16 per cent. The preceding analysis revealed that water quality was more declined as the pollution intensity was increased.

It could be observed from the table that defensive expenditure on irrigation water which was getting water from non-polluted areas was highest in severely affected farms with 2575.00 rupees per family followed by moderately affected farms with 1500.00 rupees per family and low affected farms with 800 rupees per family. Thus, as the pollution intensity was increased, defensive expenditure of irrigation water was also increased.

It could be seen from table that averting expenditure for drinking water included were getting water from non polluted areas, expenditure incurred on getting protected water and boiling water. The analysis revealed that the highest expenditure was incurred in drinking water was severely affected farms with 1162.50 rupees per family which was followed by moderately affected farms with 985 rupees per family and low affected farms with 785 rupees per family. Further, the composition of said expenditure revealed that the farmer incurred highest expenditure in purchasing protected water and it was Rs.752.50 per family, Rs.722.50 per family and Rs.625 per family respectively for severe, moderate and low affected farms. This 
was followed by boiling water with Rs. 260.00 per family, Rs. 135.00 per family and Rs.75 per family for severe, moderate and low affected farms. The expenditure incurred in getting water from non polluted areas occupied the lowest in drinking water averting expenditure. Thus it could be concluded from the table that the averting expenditure for both irrigation water and drinking water was coincided with pollution intensity.

\section{Externalities of human health}

The externalities of cement pollution on human health included chronic disease of chest pain, asthma, wheezing and kidney stone and common diseases of persistent cough with mucus, fever and running and blocking nose and the results are presented in table 5. It could be revealed from the table that the incidence of health disorders was high in severely affected farms with 84.65 per cent followed by moderately affected farms with76.78 per cent and low affected farms with 64.57 per cent.

Further, the intensity of common disease was high as compared to intensity of chronic disease due to effect of cement pollution. Even though the chronic disease incidence was less, the averting expenditure for chronic disease was higher with Rs. 1923.75 for severely affected farms, Rs. 1464.86 for moderately affected farms and Rs. 1000.64 for low affected farms. With respect to common diseases, the proportion of high severity was more in severely affected farms with 67.44 per cent. In moderately affected farms, the moderate incidences were high with 49.02 per cent. In low affected farms, the proportion of low severity was high with 42.11 per cent.Number of illness days per month was high in severely affected farms with eight days per month followed by moderately affected farms with five days per month and low affected farms with two days per month which also were directly related with pollution intensity. Finally it could be inferred from the table that the averting expenditure for both chronic diseases and common diseases was increased with pollution intensity.

\section{Valuation using environmental valuation techniques}

Various environmental externalities are valued by four different environmental valuation techniques namely production change technique, damage function, hedonic model, contingent valuation techniques and the results are discussed in this section.

\section{Production change technique}

In the present study, since negative externality was prevalent due to cement pollution, the decline in crop and animal husbandry production was analysed between severe, moderate and low affected farms with non affected farms. Since this production decline was measurable, production change technique was employed and valued at 2019 market prices and are presented in table 6 .

It could be seen from the table that the value of crop production decline due to cement pollution was highest in severely affected farms with 137089 rupees per hectare followed by moderately and low affected farms with 71030 and 21655 rupees per hectare respectively. The decline in crop production of seriously affected farms over moderately and low affected farms by 93.00 per cent and 533.06 per cent respectively.

The decline in value of animal husbandry production was also highest in severely affected farms with 29442 rupees per hectare followed by moderately affected farms and low affected farm with 11552 rupees per 
hectare and 6310 rupees per hectare. The decline in animal husbandry production of seriously affected farms over moderately and low affected farms by 154.87 per cent and 366.59 per cent respectively. Thus this decline in crop production and animal husbandry was directly related with the pollution intensity.

\section{Agricultural damage function}

Damage function included under the indirect valuation technique. The agricultural value damage function related value of agricultural damages to averting expenditure of land and irrigation water and quality indices of land and irrigation water. Log-linear regression function was attempted for estimating agriculture damage in severe, moderate and low affected farms.

\section{Severely affected farms}

The estimates of agricultural damage function for affected farms are furnished in table 7 . It could be observed from the table that the agricultural damages in these farms were highly influenced by land averting expenditure at one per cent level of significance and land quality index at five per cent significance. It could also be seen from the table that land based averting expenditure had negative influence on agricultural damage in these farms which is obvious. One per cent increases in land based averting expenditure, ceteris paribus, resulted in decreased of agriculture damage in severely affected farms by 0.19 per cent from the mean level. One per cent increase in land quality index, that is from serious to low affected, ceteris paribus, decreased the agricultural damage by 0.90 per cent from the mean level. Thus in severely affected farms, the agricultural damage could be reduced by undertaking more of land averting expenditure and improving the land quality. The land averting expenditure and land quality index was significant in these farms as land was more exposed to cement pollution and hence land pollution was more prevalent rather than irrigation water pollution.

\section{Moderately affected farms}

The result of agricultural damage function of moderately affected farms are presented in table 7 and it could be seen from the table that the agricultural damage in these farms were highly influenced by land averting expenditure at one per cent level and averting expenditure for irrigation water at five per cent level of significance. One per cent increase in land based averting expenditure, ceteris paribus, decreased the agriculture damage by 0.01 per cent from the mean level. One per cent increase water based averting expenditure ceteris paribus decrease the agricultural damage in moderately affected farms by 0.004 per cent mean level. The land and water based expenditure had negative influence on agriculture damage in these farms which is obvious. Thus the agricultural damage in moderately affected farms could be reduced by use of higher land based averting expenditure and irrigation water based averting expenditure.

\section{Low affected farms}

The results of agricultural damage function of low affected farms of sample farms are presented in table 7 . It could be seen from the table that the agricultural damages in these farms were highly influenced by land averting expenditure at one per cent level of significance and land quality index at five per cent level of significance. Increasing land based averting expenditure, ceteris paribus, resulted in decrease of agriculture damage by 0.009 per cent from the mean level. One per cent increase in land quality index, ceteris paribus decreased the agricultural yield 
damage by 0.10 per cent from mean level. Thus the agriculture damage in low affected farms could be reduced by improving the land quality index and undertaking of higher land based averting expenditure. Thus in severely affected and low affected farms, agricultural damage could be reduced by undertaking land based averting expenditure and improving land quality index. In moderately affected farms, agricultural damage could be reduced by undertaking averting expenditure of both land and irrigation water.

\section{Hedonic model}

In the present study, influence of household income and quality parameters on land value was study by this model for all categories of affected farms. The semi logarithmic form (logarithm in y) was found to be the best one for all categories of affected farms.

\section{Severely affected farms}

The estimates of value of crop land for severely affected farms are furnished in table 8. It could be observed from the table that the value of land was positively influenced by farm income at one per cent level of significance, water quality index and distance from cement factory were significant at five per cent level of significance. One rupee increase in the farm income, ceteris paribus, increased 0.45 per cent of value of crop land. One unit increase in water quality index, ceteris paribus, increased the land value by 0.95 per cent. The increase in water quality index was associated with good water quality even high pollution level and hence the positive influence of this index on land value. One kilometre increase in distance between farm and cement factories, ceteris paribus, increased the land value 1.77 per cent. The increase in distance between farm and cement factory were associated with reduced pollution level and hence the positive influence was obtained.

\section{Moderately affected farms}

In moderately affected farms, the variables of farm income, distance from cement factories in kilometres, area under fallow and land quality index had positively influenced the value of crop land and presented in table 8 . One rupee increase in the farm income, ceteris paribus, increased the value of crop land by 0.00004 per cent. One unit increase land quality index, ceteris paribus, increased the value of crop land by 0.38 per cent. Increase in the land quality index was associated with good land quality in moderately affected farms and hence the positive influence of it on land value. One per cent increase distance form cement factory to farm, ceteris paribus, increased the land value by 0.19 per cent. The increase in distance between farm and cement factory were associated with reduced pollution level as like in seriously affected farms and hence the positive influence was obtained. One hectare increase in area under fallow, ceteris paribus, decreased the value of crop land by 0.96 per cent. Area under follow had negative influence on the value of crop land which was obvious.

\section{Low affected farms}

In low affected farms, the variables of farm income, water quality index, distance between farm and cement factory had positive influence on value of cultivated land (Table 8 ). One rupee increase in farm income, ceteris paribus, increased 0.000002 per cent value of cultivated land. The irrigation water quality index, if increased by one unit, ceteris paribus, increased the land value by 0.33 per cent above the mean level. The increase in water quality index was associated with good water quality and hence had positive influence on land value. One kilo metre increase in distance between farm and cement factory, ceteris paribus, increased 0.08 per 
cent of value of crop land. The increase in distance farm and cement factory was associated with reduced pollution level and hence the positive influence was obtained.

Thus in all the affected farms, farm income and distance of farm from cement factories had positive influence on crop land. For seriously affected and low affected farms, water quality index had positive influence on value of crop land. For moderately affected farms, land quality index had positive influence on value of crop land along with area under fallow which had negative influence on crop land.

\section{Contingent valuation}

\section{Willingness to pay by affected farmers}

The Willingness To Pay (WTP) and willingness to accept compensation by affected farmers are presented in table 9. The proposition of farmer's willingness to pay was highest in severely affected farms with 86.71 per cent, followed by moderately affected farmers with 66.47 per cent and low affected farmers with 33.29 per cent which revealed that the willingness to pay increased with pollution intensity. The amount of WTP was also high for severely affected farmers with Rs 2850 per year, which was due to highest pollution intensity prevailing in these farms. For moderately affected farmers, the WTP was Rs. 1950. The amount of WTP for low affected farmers was lowest with Rs.1250 per year which was due to low pollution intensity prevailing in these farms.

In low affected category, even though the farmers were able to pay Rs. 1650 per annum, their WTP was only 54.55per cent of ability to pay which might be due to less pollution intensity prevailed in that category. For moderately affected farmers, WTP was 86.66 per cent of ability to pay. On other hand, for severely affected farmers, WTP was highest with 91.94 per cent of able to pay. The preferred mode of payment was annual payment and it was high in all the three categories of affected farms as compared to monthly payment.

\section{Willingness to accept compensation by affected farmers}

The details of willingness to accept compensation is presented in table 9. In this case, the proportion was high for low affected farmers with 61.71 per cent. For moderately affected farmers, the proportion was 33.53 per cent. The proportion of compensation was lowest in severely affected farms with a proportion of 13.29 per cent since the farmers in this category felt that the compensation principle would not be practical and time consuming. For all three categories of farmers, there was no limit in accepting compensation.

\section{Estimation of Household health Production Function}

Household production function was studied using Cobb Douglas regression technique in affected farms. The age of the respondent, household head's education, income, medical expenditure on health and health status were included as regressors and the result are presented in this section.

\section{Severely affected farmers}

Estimation of working days lost for severely affected farmers are furnished in table 10. It could be seen from the table that working days lost in these farms were influenced by age and medical expenditure at one per cent level and occupation at five per cent level. Age had positively influenced the working days lost which is quite obvious. Medical health expenditure had negatively influenced 
the working day lost because increased medical expenditure implied high illness and hence reduced the working day lost. Health status also had positively influenced the working days lost because most of the farmers suffering from chronic illness and so increased the working day lost

Table.1 Land quality deterioration in affected farms (per cent)

\begin{tabular}{|l|l|l|l|l|}
\hline S. No. & Particulars & Severe & Moderate & Low \\
\hline & Land quality & & & \\
\hline 1. & Poor & 72.50 & 27.50 & 15.00 \\
\hline 2. & Average & 27.50 & 55.00 & 62.50 \\
\hline 3. & Good & - & 17.50 & 22.50 \\
\hline
\end{tabular}

Table.2 Fallow of land and yield decline

\begin{tabular}{|l|l|l|l|l|}
\hline S.No. & Particulars & Severe & moderate & Low \\
\hline I. & Fallow land & & & \\
\hline $\mathbf{1 .}$ & Area (in ha) & 1.51 & 1.25 & 0.23 \\
\hline $\mathbf{2 .}$ & Years of fallow & 18.59 & 18.44 & 15.08 \\
\hline II. & Yield decline & & & \\
\hline A. & Quantity (q/ha) & & & \\
\hline $\mathbf{1 .}$ & Maize & 20.52 & 7.32 & 5.35 \\
\hline $\mathbf{2 .}$ & Cotton & 10.14 & 9.25 & 7.35 \\
\hline $\mathbf{3 .}$ & Sugarcane & 5.35 & 1.96 & 1.49 \\
\hline $\mathbf{4 .}$ & Groundnut & 11.19 & 10.10 & 8.36 \\
\hline B. & Reason (in per cent) & & & \\
\hline 1. & Cement pollution & 92.50 & 75.00 & 37.50 \\
\hline 2. & Drought & 7.50 & 15.00 & 50.00 \\
\hline $\mathbf{3}$ & Pest and disease & & 10.00 & 12.50 \\
\hline III. & Land value (in lakh & 16.90 & 28.63 & 32.68 \\
\hline
\end{tabular}


Table.3 Averting expenditure or defensive expenditure for land

\begin{tabular}{|l|l|l|l|l|}
\hline S. No. & Particulars & Severe & Moderate & Low \\
\hline 1. & Additional seed rate & 2353.88 & 2258.08 & 877.30 \\
& & $(16.42)$ & $(21.38)$ & $(13.60)$ \\
\hline 2. & Organic manure & 8560.00 & 6650.00 & 4650.00 \\
& & $(59.69)$ & $(62.98)$ & $(72.09)$ \\
\hline 3. & Ammonium Sulphate & 2213.85 & 1018.53 & 792.07 \\
& & $(15.44)$ & $(9.65)$ & $(12.28)$ \\
\hline 4. & Gypsum & 1212.04 & 632.81 & 131.19 \\
& & $(8.45)$ & $(5.99)$ & $(2.03)$ \\
\hline & Total & 14339.78 & 10559.42 & 6450.56 \\
& & $(100.00)$ & $(100.00)$ & $(100.00)$ \\
\hline
\end{tabular}

(Figures in parentheses indicate per cent to total)

Table.4 Water quality and Averting expenditure on water in affected farms

\begin{tabular}{|l|l|l|l|l|}
\hline S. No. & Particulars & Severe & Moderate & Low \\
\hline A. & Water quality(in per cent) & & & \\
\hline 1. & Poor & 85.57 & 30.14 & 19.00 \\
\hline 2. & Average & 14.43 & 51.43 & 44.86 \\
\hline 3. & Good & & 18.43 & 36.16 \\
\hline B. & $\begin{array}{l}\text { Averting expenditure on water } \\
\text { (Rs/ family) }\end{array}$ & & & \\
\hline 1. & Irrigation water & 2575.00 & 1500.00 & 800.00 \\
\hline 2. & Drinking water & & & \\
\hline i. & Boiling water & 260.00 & 135 & 75 \\
\hline ii. & Water from non-polluted areas & 150.00 & 126.50 & 85 \\
\hline iii. & Expenditure involved from & 752.50 & 722.50 & 625 \\
\hline & getting protected water & & & 785 \\
\hline
\end{tabular}


Table.5 Externalities on human health

\begin{tabular}{|c|c|c|c|c|}
\hline S.No. & Particular & Severe & Moderate & Low \\
\hline 1. & $\begin{array}{l}\text { Incidence of health disorders } \\
\text { family wise }(\%)\end{array}$ & 84.65 & 76.78 & 64.57 \\
\hline 2. & Chronic diseases & & & \\
\hline a. & Intensity (No.) & 7.24 & 6.48 & 3.43 \\
\hline b. & $\begin{array}{l}\text { Averting or defensive expenditure } \\
\text { (Rs.) }\end{array}$ & & & \\
\hline i. & Physician cost & 328.75 & 263.88 & 200.65 \\
\hline \multirow[t]{2}{*}{ ii. } & Treatment cost & 1595.00 & 1200.98 & 800.00 \\
\hline & Total & 1923.75 & 1464.86 & 1000.65 \\
\hline 3. & Common diseases & & & \\
\hline a. & Intensity (No.) & 22.00 & 17.25 & 12.00 \\
\hline b. & Severity (\%) & & & \\
\hline i. & High & 67.44 & 23.53 & 10.53 \\
\hline ii. & Moderate & 25.58 & 49.02 & 31.58 \\
\hline iii. & Low & 6.98 & 17.65 & 42.11 \\
\hline iv. & No & & 9.80 & 15.79 \\
\hline c. & $\begin{array}{l}\text { Averting and defensive } \\
\text { expenditure (Rs.) }\end{array}$ & & & \\
\hline i. & Physical cost & 254.05 & 195.34 & 175.56 \\
\hline \multirow[t]{2}{*}{ ii. } & Treatment cost & 795.40 & 540.98 & 325.75 \\
\hline & Total & 1049.45 & 736.32 & 501.31 \\
\hline 4. & $\begin{array}{l}\begin{array}{l}\text { Number of illness days } \\
\text { (days/month) }\end{array} \\
\end{array}$ & 8 & 5 & 2 \\
\hline
\end{tabular}

Table.6 Value estimates of production decline (in rupees per hectare)

\begin{tabular}{|l|lr|l|l|l|}
\hline S. No. & Particular & Severe & Moderate & Low \\
\hline 1. & Crop (Rs/ha) & 137089.40 & 71030.00 & 21654.76 \\
\hline 2. & $\begin{array}{l}\text { Animal } \\
\text { (Rs/farm) }\end{array}$ & husbandry & 29442.00 & 11552.24 & 6310.35 \\
\hline
\end{tabular}


Table.7 Agricultural damage function

\begin{tabular}{|l|l|l|l|l|}
\hline S. No. & Particular & Severe & Moderate & Low \\
\hline 1. & Yield damage in rupees per hectare $(\mathrm{Y})$ & & & \\
\hline 2. & Constant & $10.31^{* *}$ & $12.18^{* *}$ & $13.06^{* *}$ \\
\hline 3. & $\begin{array}{l}\text { Land averting expenditure in rupees } \\
\text { hectare }\left(\mathrm{X}_{1}\right)\end{array}$ & $-0.19^{* *}$ & -0.01 & $-0.009^{* *}$ \\
\hline $\mathbf{4 .}$ & $\begin{array}{l}\text { Averting expenditure for irrigation water } \\
\text { in rupees }\left(\mathrm{X}_{2}\right)\end{array}$ & $0.01 \mathrm{NS}$ & $-0.004^{*}$ & $0.001 \mathrm{NS}$ \\
\hline $\mathbf{5 .}$ & Land quality index $\left(\mathrm{X}_{3}\right)$ & $-0.90^{*}$ & $0.37 \mathrm{NS}$ & $-0.10^{*}$ \\
\hline 6. & Water quality index $\left(\mathrm{X}_{4}\right)$ & $-0.43 \mathrm{NS}$ & $0.18 \mathrm{NS}$ & $-0.53 \mathrm{NS}$ \\
\hline 7. & Adjusted $\mathrm{R}^{2}$ & 0.75 & 0.67 & 0.77 \\
\hline
\end{tabular}

**P $\leq 0.001$ (two tailed test), ${ }^{*} \mathrm{P} \leq 0.05$ (two tailed test) and NS -non significant

Table.8 Estimates of hedonic function

\begin{tabular}{|l|l|c|c|c|}
\hline S. No & Particulars & Severe & Moderate & Low \\
\hline 1. & $\begin{array}{l}\text { Value of crop land in } \\
\text { rupees per hectare }(\mathrm{Y})\end{array}$ & & & \\
\hline 2. & Constant & $11.17^{* *}$ & $13.81^{* *}$ & $12.85^{* *}$ \\
\hline $\mathbf{3 .}$ & Farm income in Rs $\left(\mathrm{X}_{1}\right)$ & $0.45^{* *}$ & $0.00004^{*}$ & $0.000002^{* *}$ \\
\hline $\mathbf{4 .}$ & Land quality index $\left(\mathrm{X}_{2}\right)$ & $0.29 \mathrm{NS}$ & $0.38^{*}$ & $-0.02 \mathrm{NS}$ \\
\hline $\mathbf{5 .}$ & Water quality index $\left(\mathrm{X}_{3}\right)$ & $0.95^{*}$ & $-0.20 \mathrm{NS}$ & $0.33^{*}$ \\
\hline $\mathbf{6 .}$ & Distance in Kilometres $\left(\mathrm{X}_{4}\right)$ & $1.77^{*}$ & $0.19^{* *}$ & $0.08^{* *}$ \\
\hline 7. & Area under fallow $\left(\mathrm{X}_{5}\right)$ & $0.09 \mathrm{NS}$ & $-0.96^{*}$ & $0.009 \mathrm{NS}$ \\
\hline $\mathbf{8 .}$ & $\begin{array}{l}\text { Adjusted coefficient of } \\
\text { multiple determination }\left(\mathrm{R}^{2}\right)\end{array}$ & 0.64 & 0.79 & 0.90 \\
\hline \multirow{2}{*}{$* \mathrm{P}<0.001$ (two tailed test) $* \mathrm{P}<0.05($ two tailed test) and NS -non significant } \\
\hline
\end{tabular}


Table.9 Willingness to pay and willingness to accept compensation by affected farmers

\begin{tabular}{|l|l|l|l|l|}
\hline S.No. & Particulars & Severe & moderate & Low \\
\hline 1. & Willingness To Pay & & & \\
\hline A. & Number (\%) & 86.71 & 66.47 & 38.29 \\
\hline B. & Maximum per annum (Rs) & 2850 & 1950 & 900 \\
\hline C. & Able to pay per annum (Rs) & 3100 & 2250 & 1650 \\
\hline 2. & Mode of payment & & & \\
\hline A. & Monthly (\%) & 11.74 & 20.38 & 28.67 \\
\hline B. & Annual (\%) & 88.26 & 79.67 & 71.33 \\
\hline 3. & Willingness To Accept Compensation & & & \\
\hline A. & Number (\%) & 13.29 & 33.53 & 61.71 \\
\hline B. & $\begin{array}{l}\text { Willingness to accept compensation } \\
\text { (Rs/year) }\end{array}$ & No limit & No limit & No limit \\
\hline
\end{tabular}

Table.10 Estimation of household health production function for severely affected farmers

\begin{tabular}{|l|l|l|l|l|}
\hline S.No. & Particulars & Severe & Moderate & low \\
\hline 1. & Constant & $15.49^{* *}$ & 18.77 & 12.59 \\
\hline 2. & Age of the respondent $\left(\mathrm{X}_{1}\right)$ & $1.24^{* *}$ & $0.53^{\mathrm{NS}}$ & $0.26^{* *}$ \\
\hline $\mathbf{3 .}$ & Household's Education $\left(\mathrm{X}_{2}\right)$ & $0.006^{\mathrm{NS}}$ & $-1.64^{* *}$ & $-1.73^{*}$ \\
\hline $\mathbf{4 .}$ & Household Income $\left(\mathrm{X}_{3}\right)$ & $0.71^{\mathrm{NS}}$ & $0.003^{*}$ & $-0.07^{* *}$ \\
\hline $\mathbf{5 .}$ & $\begin{array}{l}\text { Medical expenditure on } \\
\text { health }\left(\mathrm{X}_{4}\right)\end{array}$ & $-0.02^{* *}$ & $-0.12^{* *}$ & $-0.42^{*}$ \\
\hline 6. & Health status $\left(\mathrm{X}_{5}\right)$ & $1.59^{*}$ & $0.91^{*}$ & $0.58^{\mathrm{NS}}$ \\
\hline 7. & $\begin{array}{l}\text { Adjusted coefficient of multiple } \\
\text { determination }\left(\mathrm{R}^{2}\right)\end{array}$ & 0.61 & 0.77 & 0.73 \\
\hline
\end{tabular}

\section{Moderately affected farmers}

The result of moderately affected farmers is presented in table 10. It could be seen from the table working days lost were highly influenced by education and medical expenditure at one per cent level and, income and health status at five per cent level. Health status was positively influenced the working day lost, because most of farmer suffering from chronic illness and so increased the working day lost for moderately affected 
farmers as like severely affected farmers. Education had negative relationship with working day lost in moderately affected farms as these farms are highly aware of pollution consequences due to increased education. Medical health expenditure had negatively influenced the working day lost because increased medical expenditure implied high illness and consequent reduction in working day lost as like in seriously affected farms. Income had positively influenced the working days lost in these farms.

\section{Low affected farmers}

For low affected farmers, the results are furnished in table 10. It could be seen from the table that the working day lost in low affected farms was highly influenced by age and income at one per cent level and education and medical expenditure at five per cent level. Age had positively influenced working day lost because old age respondents were highly affected by the pollution. Education and medical expenditure had negative influence on working day lost in low affected farms. So, these farms are highly aware of pollution even though the pollution intensity was at low level. Thus the results of household health production function shown that working days lost by affected farmers were specific to the particular category of affected farmers.

Conclusions and Policy implications are as follows:

The study concluded that the yield decline of crops, averting or defensive expenditure for land, irrigation water and drinking water and human health was coincided with pollution intensity prevailed in affected farms caused by cement pollution. The solution to cement pollution problem should take cognizance of not only various externalities due to cement pollution but, also intensity of these externalities. Hence, appropriate schemes should be framed to reverse the damage caused to ecology and environmental specifically for each of the seriously affected, moderately affected and low affected lands.

The production change method showed decline of crop production and animal husbandry production was directly related with the pollution intensity. The valuation of agricultural damage function revealed that agriculture damage in affected farms could be reduced by undertaking more of land based averting expenditure and improving the land quality index and water quality index. The application of soil amendments was very much limited among all affected farms and for this, necessary efforts must be taken by the extension infrastructure of the Agriculture department, to motivate the farmers to apply these amendments by conducting awareness campaigns and demonstrations.

Hedonic model revealed that for seriously affected and low affected farms, water quality index had positive influence on value of crop land. For moderately affected farms, land quality index had positive influence on value of crop land along with area under fallow which had negative influence on crop land. Hence necessary efforts should be undertaking by all the concerned authorities to improve these lands by way of initiation of reclamation schemes in seriously affected farms to preserve one of the natural endowments of the region. The Government should collect the WTP amount from the polluters and pay to the victims depending on the level of pollution incidence. Health production function revealed that most of farmers suffering from chronic illness and resulted in loss of working days. So the government should conduct health awareness campaigns to mitigate this problem.

\section{References}

Amarnath, J. S., and Krishnamoorthi, S., 
(2001), "Economic Valuation of Tannery Pollution Externalities", Indian Journal of Agricultural Economics, p. 50(3): 359-360, 2001.

Amarnath, J. S., and Sridevi, U. (2016). An environmental impact assessment of sewage pollution in Madurai District. International Journal of Environment, Agriculture and Biotechnology, 1(3): 238536.

Ami, D., Aprahamian, F., Chanel, O., Joulé, R. V., and Luchini, S. (2014). Willingness to pay of committed citizens: A field experiment. Ecological Economics, 105: 31-39.

Cropper, L., Maureen and Wallace, E., Oates, 1992, "Environmental Economics: A Survey", Journal of Economic literature, p.30 (2):675-740.

Komarova, V. (2009). Valuing Environmental Impact of Air Pollution in Moscow with Hedonic Prices. World Academy of Science, Engineering and Technology, 57: 319-326.
Ligus, M. (2018). Measuring the Willingness to Pay for Improved Air Quality: A Contingent Valuation Survey. Polish Journal of Environmental Studies, 27(2): 763-771.

Liu, R., Yu, C., Liu, C., Jiang, J., and Xu, J. (2018). Impacts of haze on housing prices: an empirical analysis based on data from Chengdu (China). International journal of environmental research and public health, 15(6): 1161.

Maddison, D. (2000). A hedonic analysis of agricultural land prices in England and Wales. European Review of Agricultural Economics, 27(4): 519532.

Sun, C., Yuan, X., and Yao, X. (2016). Social acceptance towards the air pollution in China: evidence from public's willingness to pay for smog mitigation. Energy Policy, 92: 313-324.

\section{How to cite this article:}

Kayalvizhi, K., J. S. Amarnath and Sivasankari, B. 2020. An Environmental Impact Assessment of Cement Pollution in Ariyalur District of Tamil Nadu, India. Int.J.Curr.Microbiol.App.Sci. 9(10): 2348-2363. doi: https://doi.org/10.20546/ijcmas.2020.910.282 